\title{
The Causes of Conflicts and Crisis in School Management
}

\author{
${ }^{1}$ Dr. Onwe, Sunday O., ${ }^{2}$ Nwogbaga, David M. E \\ ${ }^{I}$ Department of Public Administration, Ebonyi State University, Abakaliki \\ ${ }^{2}$ Department of Political Science, Ebonyi State University, Abakaliki
}

\begin{abstract}
This paper examined the causes of conflicts and crisis in school management. The qualitative research design was adopted in gathering the information used. Essentially, the related literatures reviewed revealed that the causes of conflicts and crisis in school management as in other spheres of human existence revolve around status, power, and resource. But the causes of specific cases of conflicts and crisis vary with places, times, and circumstances; while the effects on social relations, output, and productivity largely depend on how they are managed.
\end{abstract}

Key Concepts: Conflict, Crisis, Management

\section{Methodology}

Documentary research design was applied in this study. The researcher used textbooks, internet materials and journal publications in gathering relevant information and data. These literatures were sourced from libraries and internet websites. In order to elicit the information and data relevant to the study, the contents of the literatures gathered were thoroughly read, simplified, summarised, classified and assessed with focus on the issues investigated. Consequently, the conclusions made were based on the interpretations and logical inferences drawn from the information and data generated from existing literatures.

\section{Introduction}

Conflicts and crisis have become part and parcel of the human society to the extent that the management of institutions and organisations are very cumbersome. If the opinions of managers of institutions and organisations were sought, many, if not all, would request that conflicts and crisis should be completely eliminated where possible. But as Flippo (1980) remarked, a total absence of conflict would be unbelievable, boring, and a strong indication that "conflict is being suppressed" at the expense of organisational progress. Kerzner (1998) also captured the inevitability and significance of conflict when he observed that it is an essential part of social change in the society, institutions, and organisations without which they may become redundant, dictatorial, and monotonous. There can be conflicts about (a) the perception of how things are (conflict of facts); (b) how things should or ought to be (conflict of values); and (c) who is entitled to have what (conflict of interests) (Heirich, 2006). It is therefore not an aberration to expect conflicts in school management systems. However, these conflicts and crisis sometimes grow to enormous proportions where they become detrimental to the involved parties and the organisations as their regular occurrences largely affect effective management and productivity. It is in the light the implications of conflict and crisis for management and productivity that we deemed it necessary to examine their causes in the school system.

This exposition is particularly relevant at a time when conflicts and crisis pervade and tend to mar the management of our school system against the realisation of stated educational goals and objectives. Observably, those who bear the blames of the conflicts and crisis in school management are the "Head-Teachers" otherwise addressed as headmasters, headmistresses, and principals. In the event of conflicts and crisis, Head-Teachers are crucified for their presumed incompetence in school management even though there are other key players like teaching and non-teaching staff, students, and even parents. In order to handle conflict and crisis situations effectively and efficiently, Ekundayo (2010), submitted that principals and/or head-teachers should be knowledgeable, professionally competent and resourceful and that this could be done by sponsoring them in trainings and programmes such as this, to enhance their professional growth and development.

It is therefore pertinent that the 'managers' of schools should know the causes of conflicts and crisis in school management so that they can address them properly and explore the positive effects adequately. Importantly, we shall not examine the causes of conflicts and crisis in isolation; hence, we shall also examine the perceptions, the objects, the forms, as well as the dynamics of conflicts and crisis because they are interwoven. 


\section{Perceptions of Conflicts, Crisis, and Management}

The concepts of conflict, crisis, and management have varied but closely-knit interpretations which can scarcely be divorced. While the distinction between conflicts and crisis is a function of intensity, both of them affect the accomplishment of management goals (Jean Monnet Group, 2006; Okotoni and Okotoni, 2003).

Coser (1956) defined conflict as a struggle over values and claims to scarce status, power, and resources in which the aims of the opponents are to neutralise, injure, or eliminate their rivals. This definition corroborated the earlier assertion by Hansfield (1943) that conflict refers to a breakdown of normal activities of an organisation in such a manner that the individual or group involved experience disharmony in working together. These definitions imply that the individuals or groups involved in conflict will not just stop working together as a team, but can go on to devise means, strategies, and tactics to frustrate and mar the efforts and intents of the perceived opponent(s). This submission is captured by Pondy (1969) when he explained that conflict ranges from passive resistance to active aggression. Essentially, Flippo (1980) noted that conflict occurs when two or more people or group perceive that they have (a) incompatible interests or positional differences (b) interdependent activities towards attaining the goals. Hence, as Katz and Kann (1978) rightly pointed out, persons, groups, organisations and nations engage in conflict when they interact directly in such a way that the actions of one tends to prevent or compel some outcomes against the resistance of another (cited in Odoh, 2006). Meanwhile, conflict refers to disagreements, misunderstanding, disharmony, confrontations, and struggles over values (status, power, resources) arising from clash of interests and interdependence of activities, which may or may not be expressed violently.

It is the violent expression of conflict that scholars termed Crisis (Jean Monnet Group, 2006; Okanya, 1999). As explained by the Oxford Advanced Learners' Dictionary (2000), crisis refers to a situation or condition of serious danger, difficulty, or uncertainty when problems must be solved or important and critical decisions must be made to avert grave consequences. In essence, crisis is not anything quite different from conflict but just a violent escalation of disagreements and struggles over values and claims. According to Sandole (1998), non-violent conflict translates into crisis (violent conflict) when parties go beyond seeking to attain their goals by peaceful means, and try to dominate, damage, or destroy the opposing parties' ability to pursue their own interests. This observation agrees with the earlier position of Davies (1973) that crisis which is the violent expression of conflict is produced when certain innate needs or demands are deeply frustrated to the extent that the affected party resorts to causing physical damages and human casualties. Thus, while conflict refers to disagreement between two or among more parties resulting in mere positional differences and tensions, crisis means the violent expressions of unresolved discontents. This minute distinction compelled Pfetsch (1994) to categorise conflict and crisis into five-types based on intensity (non-violent and violent) as contained in the table below.

Table 1: Forms of Conflict Based on Intensity

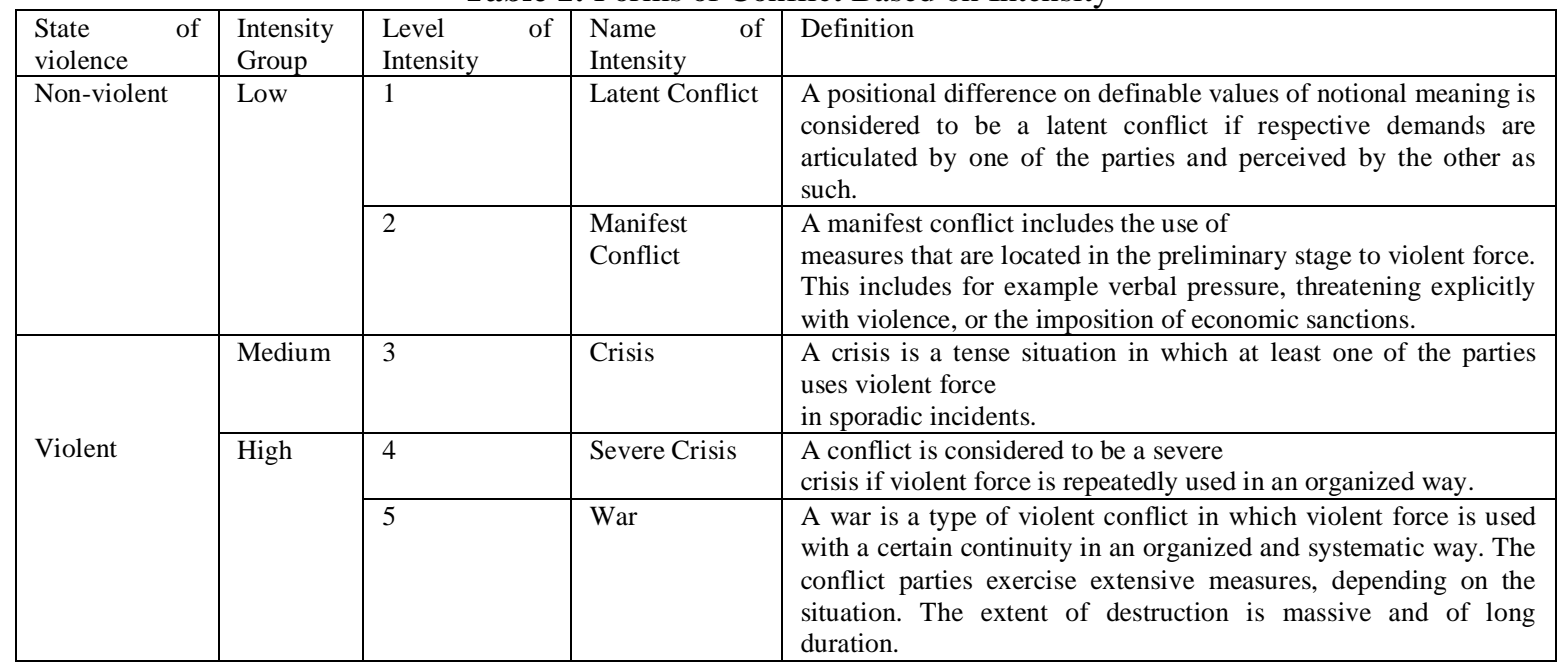

Source: HIIK (2005)

Based on the contents of the table above:

1. Latent conflict exists when values, issues or objectives are questioned with some identifiable and observable signs which occasion positional differences and clash of interest articulated as demands and claims.

2. Manifest conflict exists when tensions are present but are expressed by means below the threshold of violence such as quarrels, threats, warnings, intentional disobedience and non-compliance to directives, 
negligence of duty, detachments and withdrawals from normal activities, and irresponsiveness to greetings and compliments etc.

3. Crisis occurs when there is sporadic use of violence that causes damage to symbols, lives and property.

4. Severe crisis involves repeated use of force in an organised way with preparations.

5. War incorporates the use of force and violence with plans for sustainability and continuity in organised and systematic way.

Meanwhile, conflicts and crisis are essential aspects of management which determine its successes or failures (Okotoni and Okotoni, 2003). The concept of management has various uses which could mean different things to different people in different contexts. Management could be used to refer to a field of study or academic discipline, authorities of an organisation or institution, or the art and process of organisational governance (Ekundayo, 2010; Okotoni and Okotoni, 2003). In this context, management refers to the art and process of governing, running, administering organisations and institutions through designated authorities. Following this line of thought, Sisk and William (1981) defined management as a process of coordinating all resources through planning, organising, leading and controlling in order to attain or achieve stated objectives which border. In our educational system, the broad objective of management is to enhance efficiency and effectiveness in the nation's course of human resources development (Fabumi, 2005). Certainly, effective management does not just happen, but is brought about by individuals who possess the knowledge and skills to synchronise the actions of numerious people and channel those actions towards a common goal (Duncan, 1975). Invariably, management consists of all organisational activities that involve formation of goals, attainment of the goals, appraisal of performances and the development of mechanisms that will ensure the success and the survival of the organisation within the social system (Okotoni and Okotoni, 2003). As earlier noted, conflicts and crisis pervades all aspects of human activities such as the management of schools and they affect the accomplishment of the stated goals depending on the outcomes and how they are managed.

Without prejudice to the forms of conflict identified earlier, organisational conflicts may be classified into horizontal conflict (coordinate and equal hostile relations), vertical conflict (subordinate-superior hostile relations), and role confusion conflict (undefined and/or overlapping functions) (DeCenzo, 1997). These classifications are largely rooted on management communication routes. Nonetheless, they are not unconnected with the classification of conflict forms based on intensity. A significant observation in the foregoing expositions is that irrespective of the forms and levels of conflicts and crisis anywhere and anytime, the bone of contention border on values (status, power, and resources) even though the specific object(s) may vary.

\section{The Causes of Conflicts and Crisis}

Various explanations on the causes of conflicts and crisis in human society abound. Essentially, we have two broad theoretical explanations: the micro theories and the macro theories.

The major assumption of the micro theories otherwise called the behaviourist theories is that the root causes of conflict and crisis are in the human nature and human behaviour (Robert, 1989; William, 1998; Odoh, 2006). Hence, there is a strong correlation between intrapersonal conflict and the conflict that pervades the external social order. Invariably, the central driving force is the stimulus-response proposition which suggests that humans possess either biological or psychological characteristics that would predispose us towards aggression. As a result, they identified the animal behaviour theory, instinct or innate theory, frustrationaggression theory, social learning theory, and social identity theory, to explain why conflict and crisis occur. The animal behaviour theory asserts that human beings are part and parcel of the animal kingdom whose behaviour cannot be different from the rest of the animals especially on issues that involve such motivational factors as territoriality, dominance, sexuality, and survival (Robert, 1989, cited in Onwe, 2006). The instinct or innate theory suggests that conflicts and crisis are caused by inherent biological genetic factors hinged on Sigmund Freud's 'death instict' and Charles Darwins 'fight for survival' postulations (Odoh, 2006). The social learning theory avers that conflict and crisis among individuals are learnt through the process of socialisation which affects the development of a personality (William, 1998, cited in Odoh, 2006). Furthermore, the social identity theory strongly contend that conflict and crisis emanate from the quest to satisfy human needs and achieve positive self-esteem and self-worth which we transfer to our own group at the expense of another individual's group; hence, the concept of in-group Vs out-group clash (Burton, 1990). The frustration aggression theory portends that conflicts and crisis are caused when an actor frustrates or tries to frustrate the efforts of another towards achieving desired goals and objectives (Okanya, 1999; Nweke, 2006).

In line with the postulations of the micro theorists, conflict and crisis in school management are caused by motivations and material expectations, quest for dominance and survival needs, personality characteristics and the protection of identity needs, bad companionship, and the frustration of goal-oriented efforts. This position was corroborated by Okotoni and Okotoni (2003) when they identified personality clashes, inferiority/superiority complexes, misunderstanding of motives, and youthful exuberances, as the causes of conflicts and crisis in the secondary schools of Osun state. 
On the other hand, the macro theorists explain that conflicts and crisis arise from the interaction of groups specifically on the conscious level rather than individuals at the unconscious or subconscious levels (Odoh, 2006; Onwe, 2006). In other words, the root causes of conflict and crisis stem from group competition and the pursuit of power and resources (Horowitz, 1985; Otite, 1999). Essentially, the macro theorists identified balance of power theory, decision-making/games theory, and the enemy system theory to explain the various cases of conflict and crisis that pervade human existence. The balance of power theorists posit that conflicts and crisis are caused by the competition for positions of power, authority, and influence (Rourke and Boyer, 2002). This postulation is expressly captured in the dictum that in social existence, human beings strive to be equal, equal to be superior, and that is the spirit that breeds revolution (conflicts and crisis). The decision making theory hold that conflict and crisis result from the clash of opinions and views among individuals or groups in the process of deliberations on vital issues (Karen, 1999); while the game theory contends that conflict and crisis in human existence are the functions of competitions for resources that largely depend on the efficacy of applicable strategies and tactics to win or lose (Karen, 1999). The enemy system theory on its part suggests groups of people have categorised themselves as distinct from others who should be seen as enemies always and everywhere (Tajfel, 1981).

Based on the expositions of the macro theories, one may be right to adduce that conflicts and crisis in school management arise as a result of competitions for positions of power, authority, and influence; divergent opinions over vital issues that require critical decisions; and deep hatred for particular individual or group whereas others are seen as friends. Okotoni and Okotoni (2003) also captured this by including forceful retirement/retrenchment of workers, administrative incompetence of principals, misappropriation and embezzlement of school fund, negligence of duty, favouritism, and role confusion, as the causes of conflicts and crisis in secondary school management.

\section{Summary}

The causes of conflicts and crisis in school management revolve around status (personality, identity, etc), power (quest for dominance, positions of authority with the associated responsibilities), and resources (financial benefits, material benefits, welfare packages etc). Hence, in different schools and different times, conflicts and crisis in the management processes are variously caused by:

i. Style of management (authoritarian, dictatorial)

ii. Personality clash (who is who status-wise?)

iii. Identity needs and contests (e.g. indigene vs non-indigene dichotomy, differences in religious doctrines)

iv. Discriminations, favouritism, and undue influences

v. Interferences in the performance of duties and responsibilities

vi. Negligence of duty

vii. Financial irresponsibility

viii. Contests for positions of authority and responsibilities

ix. Promotional and motivational factors

$\mathrm{x}$. Influence peddling

xi. Misperceptions of motives, decisions, and actions

xii. Differences in goals and differences in the perception of management realities.

xiii. Inequitable distribution of welfare packages

xiv. irregular or non-payment of salaries and wages, improper termination of appointments

xv. Breach of collective agreements, and anti-union actions

xvi. Cumbersome grievances and dispute procedure etc

\section{Conclusion}

Conflicts and crisis in school management have diverse causes which vary with places and times; the effects can be negative and/or positive depending on how they are managed. Notably, the explanatory relevance of the different theories that offer explanations on the causes of coflicts and crisis in the area of school management largely depend on the contexts and circumstances. In other words, as schools and the management authorities are different, so are the causes of the associated conflicts and crisis. Accordingly, the strategies for avoiding or resolving the conflicts and crisis also vary with places and times.

\section{References}

[1]. Burton, R. (1990): "Readings in Conflict Management and Resolution". Hampshire and

[2]. Burton, J. (1990): “Conflict: Human Needs Theory". London: Macmillan.

[3]. Coser, L. (1956): "The Functions of Social Conflict”. New York: Free Press.

[4]. Davies, J.D. (1973): “Aggression, Violence, Revolution, and War”, in Jeanne N. K. (ed.), Handbook of Political Psychology, San Francisco, pp. 234-260

[5]. DeCenzo, D.A. (1997): "Human Relations, Personal and Professional Development”. New Jersey: Prentice-Hall, Inc.

[6]. Duncan, W.J. (1995): "Essentials of Management". Illinois: The Dryden Press.

DOI: 10.9790/0837-191250812 www.iosrjournals.org $\quad 11 \mid$ Page


[7]. Ekundayo, H.T.(2010): “Administering Secondary Schools in Nigeria for Quality Output in the 21st Century: The Principals Challenge", in Euronpean Journal of EducationalStudies 2(3). Ozean Publication.

[8]. Fabumi, M. (2005): "Historical Analysis Of Educational Policy Formulation In Nigeria: Implications For Educational Planning And Policy", in International Journal ofAfrican \& African American Studies Vol. IV, No. 2, Jul 2005

[9]. Flippo, E.B. (1980): "Personnel Management". New York: McGraw Hill Book Company.

[10]. Hansfield, cited in Odoh, S.I. (2006): "The Concepts and Theories of Conflict", in Odoh, S.I. and Onuoha, J. (eds)(2006): Peace and Conflict Studies in Africa. Enugu: JonesCommunications Publishers.

[11]. HIIK, (2005)(ed): "Conflict Barometer 2005: Crisis, Wars, Coup d'Etat, Negotiations, Mediations and Peace Settlements", Heidelberg, http://www.rzuser.uniheidelberg.de/ Ischeith/CoBa05.pdf.

[12]. Horowitz, D. (1985): "Ethnic Groups in Conflict”. Berkley: University of Carlifornia Press.

[13]. Jean Monnet Group (2006); “Conflict: A Literature Review”. Department of Social Sciences; Institute of Political Science; online: www.europeanization.de

[14]. Karen, M. (1999): “Essentials of International Relations". New York: W.W. Norton and Company.

[15]. Kerzner, H. (1998): "Project Management: A System Approach to Planning, Scheduling, andControlling". New York: John Willey and Sons, Inc.

[16]. Nweke, E. N. (2006): "Political Conflicts in Nigeria", in Odoh, S.I. and Onuoha, J.(eds)(2006): Peace and Conflict Studies in Africa. Enugu: Jones CommunicationsPublishers.

[17]. Odoh, S.I. (2006): "The Concepts and Theories of Conflict", in Odoh, S.I. and Onuoha, J. (eds)(2006):Peace and Conflict Studies in Africa. Enugu: Jones CommunicationsPublishers.

[18]. Okanya, D.O. (1999): "Political Violence in Nigeria: The Experience Under the Second Republic".Enugu:Auto-Century Publishing Company Limited.

[19]. Okotoni, O. and Okotoni, A. (2003): "Conflict Management in Secondary Schools in Osun State, Nigeria", in Nordic Journal of African Studies 12(1): 23-38.

[20]. Onwe, S. O. (2006): "The Root Causes of Conflicts and Violence in Africa", in Odoh, S.I. and Onuoha, J. (eds)(2006): Peace and Conflict Studies in Africa. Enugu: JonesCommunications Publishers.

[21]. Otite, O. (ed) (1999): “Community Conflicts in Nigeria: Management, Resolution, and Transformation". Ibadan: Spectrum Books.

[22]. Oxford Advanced Learners' Dictionary (2000)

[23]. Pfetsch, F.R. (1994): "Internationale Politik", Stuttgart.

[24]. Pondy, I. R. (1969): "Varieties of Organisational Conflicts". Administrative Science Quarterly, pp. 499-505

[25]. Rourke, J. T. and Boyer, M. A. (2002): World Politics: International Politics on theWorldStage.USA:McGraw-Hill BookCompany.

[26]. Sandole, D. (1998): “A Comprehensive Mapping of Conflict and Conflict Resolution: A Three Pillar Approach”, in Peace and Conflict Studies, 5/2, http://www.gmu.edu/academic/psc/sandole.htm

[27]. Sisk, H. L. And William, J.C. (1981): "Management and Organisation". Ohio-South Western Publishing Co.

[28]. Tajfel, H. (1981): "Human Groups and Social Categories". London: Cambridge University Press. 